\title{
Trincheiras na formação de professores de artes visuais compartilhando subjetividades
}

SILVIA CARLA MARQUES COSTA

Resumo

Esta pesquisa busca analisar através de imagens, escolhidas pelos alunos do curso de Licenciatura em Artes Visuais da Universidade Federal do Amapá como eles representam o "ser professor". Tem como foco as relações entre visualidade e subjetividade envolvidas no processo de construção de identidade docente durante o período de formação profissional. A coleta de dados será feita através de entrevistas individuais com os discentes do 5 período que não tenham experiência em sala de aula como professores e num segundo momento grupos focais. $\mathrm{O}$ estudo pretende discutir concepções de "ser professor" e como a experiência cultural contribui para a construção desse significado. 